\title{
The nexus of oil, conflict, and climate change vulnerability of pastoral communities in northwest Kenya
}

\author{
J. Schilling ${ }^{1,2}$, R. Locham ${ }^{3}$, T. Weinzierl ${ }^{1}$, J. Vivekananda ${ }^{2}$, and J. Scheffran ${ }^{1}$ \\ ${ }^{1}$ University of Hamburg, Institute of Geography, CLISEC, Hamburg, Germany \\ ${ }^{2}$ International Alert, London, UK \\ ${ }^{3}$ Danish Demining Group, Lodwar, Kenya \\ Correspondence to: J. Schilling (janpeter.schilling@uni-hamburg.de)
}

Received: 22 May 2015 - Published in Earth Syst. Dynam. Discuss.: 16 July 2015

Revised: 13 October 2015 - Accepted: 21 October 2015 - Published: 3 November 2015

\begin{abstract}
Turkana, in northwest Kenya, is the country's poorest and least developed county. Pastoralism in Turkana is well adapted to the harsh climatic conditions, but an increase in drought frequency associated with global climate change and intensifying violent conflicts between pastoral groups poses significant challenges for local communities. The conflicts are especially violent in the border region between the Turkana and the Pokot communities. In this very region significant oil reserves have recently been found. The first aim of this paper is to analyse how the oil exploration affects the communities' vulnerability to climate change. Secondly, the paper explores the risk of the oil explorations creating new conflicts or aggravating existing ones. The primary method of the study is qualitative field research supplemented with a geo-spatial analysis of conflict data. The field research was conducted in October 2013 and April 2014 in three villages with different levels of engagement with the oil exploration. At the time of the research, oil exploration was expected close to Lokwamosing, while it had recently started in the vicinity of Lopii and had been ongoing for a longer time close to Nakukulas. The findings suggest that the oil exploration increases the community's vulnerability to climate change. Further, unmet community expectations for water, employment and development pose a significant risk for violent conflict between local communities and the operating oil company. Intercommunal conflict over water and land could increase as well.
\end{abstract}

\section{Introduction}

Agriculture and pastoralism are the dominant sources for food production and income generation in Africa (World Bank, 2014). Especially in arid and semi-arid regions such as Turkana in northwest Kenya, pastoralism is a well-suited livelihood and production system that makes efficient use of the highly limited water and pasture resources (Levine, 2010; Koocheki and Gliessman, 2005). But pastoralism across the African continent is often viewed by national governments as being "backward" and partly even "primitive" (see Pavanello, 2009; Devereux, 2010). Views like these have resulted in political, economic and social marginalisation and discrimination of pastoral communities (Government of Kenya, 2007). Turkana is no exception. Here, the limitation of pastoral mobility by the government of Kenya and the neighbouring governments (mainly Uganda and Ethiopia and partly South Sudan) has decreased the adaptive capability of pastoralists (Schilling et al., 2014). This is particularly critical as an increase in rainfall variability and higher drought frequency, associated with global climate change, pose significant challenges for pastoral communities (Schilling et al., 2014; Opiyo et al., 2014). However, most detrimental to the resilience of Turkana pastoralists and their livelihood in general are the violent conflicts between pastoral groups. Each year hundreds - some sources suggest thousands - of people lose their lives in violent attacks, called raids, executed to acquire livestock or gain control over water points and pasture resources (Schilling et al., 2012b; CEWARN, 2010; Adem et al., 2012). Within Turkana the conflicts are particularly violent in southern Turkana, where the Pokot of Kenya and Uganda raid the Turkana and vice versa (Mkutu, 2006, 2010; 
Schilling et al., 2012b). In this conflict-affected, underdeveloped (in the formal sense) and water-scarce area, significant oil reserves have recently been discovered (Vasquez, 2013; see also Anderson and Browne, 2011). The dimensions are immense. The main basin in Turkana alone contains more than 600 million barrels of oil according to the UK-based operating company Tullow Oil (Tullow, 2014c). The commercial viability has been confirmed and Tullow's exploration director concludes that "northern Kenya has the potential to become a significant new hydrocarbon province" (Tullow, 2014c). For the government of Kenya the discovery of oil is "very good news" (Government of Kenya, 2012), as former president Kibaki stated after first oil explorations in 2012.

For the pastoral communities the effects of the oil exploration are likely to be more ambivalent. But how ambivalent? A review of existing studies on pastoralism and oil provides little ground to answer this question, simply because there are very few studies on oil exploration, pastoralism, conflict and climate change. For Kenya there has so far been only one study, but Johannes et al. (2014) do not specifically focus on vulnerability to climate change. The authors conclude that oil is part of "a tinderbox of risk and opportunism for violent conflict, lawlessness, and potential armed rebellion" (Johannes et al., 2014).

Most other studies on the topic have focused on (South) Sudan. For pastoralists in Sudan already confronted with militarisation of inter-ethnic conflicts and displacement, oil is an additional worry (Chavunduka and Bromley, 2011). Chavunduka and Bromley (2011) conclude that "oil has not engendered peace and prosperity but the exact opposite". Similarly, Pantuliano (2010) finds that oil exploitation in Sudan has contributed to environmental degradation, for example through tree cutting for oil extraction sites, which in turn has exacerbated conflict over land (see also Switzer, 2002). Further, unmet expectations of pastoralists for employment in the oil sector have led to attacks on oil sites and contributed to insecurity. But Pantuliano (2010) also points to positive aspects of the oil exploitation. The road infrastructure and hence the mobility has improved as a result of the presence of the oil industry. Along the oil roads new settlements and markets have emerged, opening new opportunities for trade and development.

Beyond (South) Sudan, there are several studies exploring the effects of oil exploitation on communities, although not on pastoralists. Particularly in Nigeria, the detrimental effects of oil exploitation on the environment and the communities are well studied (for example, Aghalino, 2009; Anifowose et al., 2012; Ikelegbe, 2001; Obioha, 2009; Osuji et al., 2004). Given the significant revenues earned with oil and the persistent high levels of insecurity and urban poverty, oil has mostly become a "resource curse" for communities in rural Nigeria (Sala-i-Martin and Subramanian, 2013; Obi, 2012; Idemudia, 2012). For example, unfair distribution of oil revenues has been reported as a major cause of attacks on oil pipelines and raids of oil sites (Anifowose et al., 2012). In
Angola the exploitation is similarly viewed as mostly negative for rural development (Amundsen, 2014; Wenar, 2013; Hammond, 2011). For Uganda, International Alert identifies conflict risks associated with oil, but the peacebuilding organisation also stresses the opportunities of "harnessing oil for peace and development" (International Alert, 2009; see also Vokes, 2012).

The overall aim of this paper is to explore the interactions between oil exploration, conflict and vulnerability of pastoral communities to climate change. This aim is divided into two specific research questions. First, how does the oil exploration affect the communities' vulnerability to climate change? Second, what is the risk of the oil exploration creating new conflicts or aggravating existing ones? To address these questions, field research was conducted in October 2013 and April 2014 in Turkana South. Specifically, the three villages of Lokwamosing, Lopii and Nakukulas were chosen so as to be able to compare communities with different levels of engagement with the oil exploration. The qualitative research was supplemented with a geo-spatial analysis of conflict data in Turkana. More details on the methods are described in the following section before the results are presented and conclusions are drawn.

\section{Methods}

\subsection{Research area}

The study was carried out in the county Turkana, located in northwest Kenya (Fig. 1). Nomadic pastoralism is the main livelihood in Turkana. Water, pasture, land and livestock (mainly cattle, goats, sheep and camels) are the key resources for the population. The lack of formal education, the poor level of health and road infrastructure, and the limited existence of businesses (mostly concentrated in Lodwar) offer the Turkana population very few opportunities in the formal job market (UNDP, 2010, 2006). Turkana has a poverty rate of $94 \%$. About $76 \%$ of the population have never attended a school (Kenya Open Data, 2011a, b). In their "National policy for the sustainable development of arid and semi-arid lands", the government of President of Kenya (2007) acknowledges the marginalisation of Turkana and the government's failure to integrate Turkana into the national economy. Insecurity related to pastoral conflicts, violent livestock raids and proliferation of small arms is widespread in Turkana (see Adem et al., 2012; Wepundi et al., 2012; Schilling et al., 2012b; Fig. 1 and Sect. 3.2).

The climate in Turkana is semi-arid to arid and characterised by a bimodal rainfall pattern with "long rains" between October and December and "short rains" between March and May (McSweeney et al., 2012). Reliable climate data are mostly available for Lodwar, the county capital of Turkana. In Lodwar the annual rainfall ranges from $500 \mathrm{~mm}$ in particularly wet years to less than $50 \mathrm{~mm}$ in drought years (Schilling et al., 2014). 


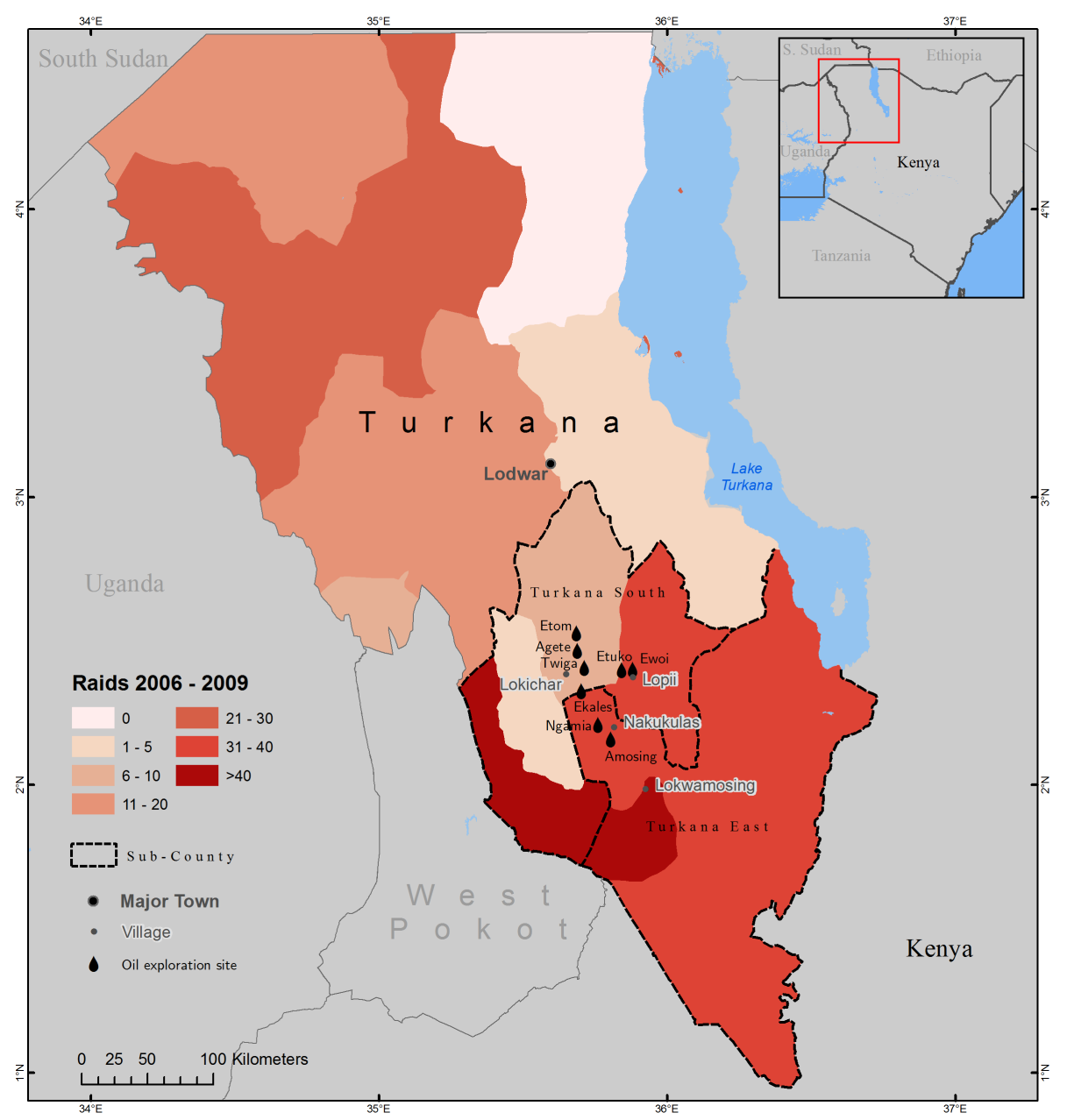

Figure 1. Research location, oil exploration and distribution of raids in Turkana (based on TUPADO, 2011; Tullow, 2014b).

The average annual temperature in Lodwar is usually above $30^{\circ} \mathrm{C}$. Global climate change is likely to lead to temperature increases and a more variable and less predictable rainfall pattern in Turkana (Schilling et al., 2014; McSweeney et al., 2012). Both trends are likely to increase the drought risk. Droughts, a historically common phenomenon in Turkana, have already been occurring more often in the past decades (Mude et al., 2009; Opiyo et al., 2015). In general, water is a scarce resource in Turkana. Lake Turkana is the only permanent source of water, although with a high salt concentration. Apart from several smaller ephemeral rivers (called laghas), the semi-permanent rivers Turkwel and Kerio are the only source of freshwater (see also Kenya Open Data, 2014a).

Within Turkana, the study was conducted in the subcounties Turkana South and Turkana East (Fig. 1). The counties cover an area of about $18670 \mathrm{~km}^{2}$ and have a population of about 226000 people (Kenya Open Data, 2014b). The villages of Lopii, Nakukulas and Lokwamosing were chosen for the field research to be able to compare different levels of engagement with the oil exploration.

Lokwamosing is furthest away from any oil exploration site. At the time of the research, members of the community in Lokwamosing had only heard about oil exploration and had not had contact with any oil company. Oil exploration had recently started in the vicinity of Lopii. Community members in Nakukulas had the most engagement with Tullow. Ngamia is the first and most developed onshore exploration site in Kenya. When the exploration at Ngamia started in January 2012, over $200 \mathrm{~m}$ of net oil pay were found (Tullow, 2013b). Net oil pay refers to the thickness of rock that can deliver oil to the well at a profitable rate (Tiab and Donaldson, 2012). Ngamia is located in the Lokichar Basin, containing more than 600 million barrels of oil (Tullow, 2014c). All three villages fall within the oil exploration block 10BB, which is held by Tullow (50\%), Africa Oil (10\%) and Lion (10\%). Tullow is the only operator, while the others hold a "non-operated interest" (Tullow, 2014c). Ngamia and Amosing are already in the phase of 
appraisal drillings (for the different phases see Cairn, 2015; for recent updates see Africa Oil, 2015). The recent period of low oil prices has forced Tullow to cut its global exploration and appraisal budget from USD 300 to 200 million (Financial Times, 2014). Estimates of when production of oil could start in Kenya range from as early as 2015 to later than 2020 (Daily Nation, 2015; Standard, 2015; Financial Times, 2015; LAPSSET, 2015). The commercial production of oil in Kenya could reach 100000 barrels per day (Standard, 2015). How fast Kenya will become an oil exporter will also depend on the oil pipeline, proposed to run over a distance of $850 \mathrm{~km}$ cutting through the country from Turkana to a maritime terminal in Lamu, located at the coast of southeast Kenya (Tullow, 2014a). The pipeline will be part of a huge infrastructure project called LAPSSET (Lamu Port-South Sudan-Ethiopia Transport). The aim of LAPSSET is to connect South Sudan and Ethiopia with Kenya's coast through railways, roads and oil pipelines (President of Kenya, 2015). Lokichar in Turkana will become a hub of the project. The governments of Kenya and Uganda recently settled on a pipeline to transport oil from Albertine, Uganda, to Lokichar. The pipeline is estimated to cost KSH 400 billion (KSH: Kenyan shilling) (USD 4.8 billion) and to be completed in 2020 (LAPSSET, 2015)

\subsection{Data collection}

Data collection for this study was carried out in October 2013 and April 2014. The main research method applied was a qualitative approach based on individual interviews, small group interviews, focus group discussion and observations. In total 124 persons participated in the study. Most of them were community members including women, pastoralists, elders, youths and village chiefs. To pick up on potential gender differences, men and women were interviewed in separate as well as in mixed groups. Each interview or focus group discussion was conducted by at least two researchers to increase objectivity. Interviews and focus group discussions were audio-recorded, unless people did not agree to be recorded. In each village, about the same composition and number of people were sampled. Individual interviews were conducted with each village chief or assistant chief, other government representatives and a few members of nongovernmental organisations (NGOs) working in the research area. For example, a discussion was held with a group consisting of local NGO representatives and local businessmen working on natural resources in Turkana South.

All efforts were made to get interviews with, or statements from, Tullow oil representatives, but the requests were denied. The research team spoke to a few Tullow community liaison officers (CLOs), but these were not formal interviews from which direct quotes could be used. The atmosphere was partly tense, especially in Nakukulas, where the purpose of the research had to be explained extensively prior to the survey.
The individual and small group interviews were based on an interview guideline structured along the themes of "general changes", "worries" and "expectations/hopes". To avoid biasing responses, terms such as "oil", "conflict" and "climate" were only used by the researchers after respondents used them first. Further, participating and non-participating observations were conducted. These were particularly useful to assess sensitive issues such as interactions between Tullow representatives and communities as well as the operations of the oil exploration itself.

The secondary research method of this study is quantitative. Data on livestock raids in Turkana, collected by the local NGO Turkana Pastoralist Development Organization (TUPADO), were analysed using Excel (for a more detailed description of the conflict data see Schilling et al., 2012b). The data were then geo-referenced using ArcGIS to show the distribution of raids and the location of oil exploration sites within Turkana (see Fig. 1 and Sect. 3.2.2). The analysis is limited to 2006 to 2009 as the reporting was only consistent in this period.

In addition, an in-depth review of the literature on pastoralism, conflict, oil and climate change was conducted and newspaper articles and press releases by oil companies operating in Turkana were studied. The research team also drew on experience gained over 5 months in 2011 during field research on conflict and climate change in Turkana (see Schilling et al., 2012b, 2014).

Like every study, the present one has its limitations. The sample size is limited to three villages and the perspective of Tullow could not be captured directly. The latter could in part be compensated for by informal conversations with Tullow representatives and a review of Tullow press releases. And while three villages are not representative of Turkana as a whole, this is to the authors' knowledge one of the first studies that explores the oil-conflict-pastoralism-climate nexus in Kenya.

\subsection{Conceptual framework}

The study applies a conceptual framework based on agents who each have a certain capability and motivation to pursue certain goals. This approach has been developed by Scheffran et al. (2012) and previously applied to the TurkanaPokot conflict (see Schilling et al., 2012b). Motivation is commonly understood as the process that initiates, guides, and maintains goal-oriented behaviours. Capability is the ability to execute a certain course of action (Scheffran et al., 2012). This relates to skills, knowledge, experience and networks on the one hand and financial resources and physical means such as men, weapons and ammunition on the other. Each actor has the choice between investing resources into a cooperative path, which implies trying to work with other actors, or into a conflicting path, which implies pursuing aims in a forceful manner (Fig. 2). 
Figure 2 shows that if one actor chooses the conflict path the other actor almost has to take this path as well to avoid disadvantages. In theory, mutual cooperation has the potential to generate the highest overall benefit for all actors as no resources are wasted for destructive purposes.

To be able to apply the described framework, key terms need to be defined. Violent conflict is defined as the forceful settlement of opposing views. In contrast, cooperation is the peaceful sharing of resources and a state in which differences are reconciled peacefully. Climate change relates to long-term changes in temperature and rainfall (IPCC, 2013). These interact with environmental changes, for instance land degradation, which in turn are driven by human action (e.g. over-exploitation of land). Vulnerability, specifically the vulnerability of the communities in Lokwamosing, Lopii and Nakukulas, is commonly divided into the three elements of sensitivity, exposure and adaptive capacity (IPCC, 2014). Sensitivity is determined by the effect of climate change on a particular resource (for instance water), its availability and how important the resource is for a certain actor (Schilling et al., 2012a). Climate exposure is the rate and extent of temperature and precipitation changes that a region is exposed to. The exposure to climate change interacts with exposure to environmental changes, for instance water pollution. It is hence important to consider the climate exposure in conjunction with the environmental exposure (see, for example, Schilling et al., 2013). Adaptive capacity relates to the actor's knowledge, skills, options and assets to adapt to climatic changes (IPCC, 2014). Since risk is a central term of this study, it is important to define it as well. Risk is understood as a product of the likelihood of an event happening and its (potential) impact (Scheffran et al., 2012).

\section{Results and discussion}

The results section is structured along the two research questions. In the first section the effects of the oil exploration on the communities' vulnerability to climate change are presented. The second section addresses the risk of the oil explorations creating new conflicts or aggravating existing ones.

\subsection{Oil exploration and community vulnerability}

Figure 3 summarises the effects of oil exploration on the communities' vulnerability to climate and environmental change. Each element of sensitivity, environmental exposure and adaptive capacity is worded to have the same sign as the respective category. For instance, the higher the water scarcity and dependence on pastoralism, the higher the sensitivity. Major current and future effects are shown in bold. Land and especially water use are the issues contributing most to community vulnerability. In the future, the issues of water extraction, pollution and soil degradation are likely to become more prominent. Elements of the adaptive capacity of the communities are likely to have improved due to

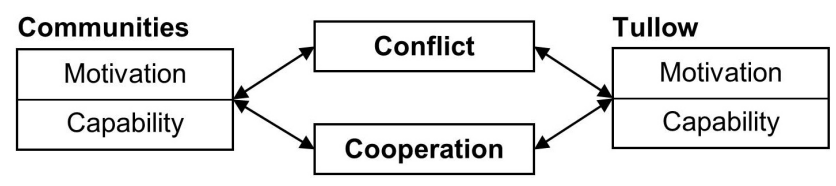

Figure 2. Framework on conflict and cooperation (adapted from Schilling et al., 2012b).

Tullow's payments to the communities and investments into education. In the future, there is a risk that the pipeline between the extraction site and the refinery will disrupt migration routes of the Turkana and other pastoral groups in the area. Overall, the oil exploration and particularly the oil exploitation are likely to make the communities more vulnerable to climate change. The following sections describe each element of vulnerability in more detail.

\subsubsection{Sensitivity}

Water and land (including pasture) are already scarce resources in Turkana. Oil exploration and exploitation aggravates water scarcity as significant amounts of groundwater are needed in every step (including drilling, injection, completion, and fracturing) (Allen et al., 2011). Studies from Canada, for instance, show that about three barrels of water are needed to extract one barrel of oil (Ptacek et al., 2004). Tullow aims to produce 100000 barrels of oil per day in Kenya and mainly in Turkana (Standard, 2015). This will likely be felt in the mid- to long run, while in the short run Tullow has improved the communal access to water through the installation of water tanks along the main road and in Nakukulas and Lopii. Community members reported that these tanks are filled by Tullow with water trucks.

Further, the extraction of oil in Turkana has the potential to offer some direct and indirect employment opportunities with Tullow and stimulation of the local economy, for example in the nearby town of Lokichar. Both could to a certain extent decrease the communities' dependence on pastoralism and hence make it less sensitive to climatic and environmental changes (Fig. 3). However, given that the effect of oil extraction on local employment is limited (see Sect. 3.2.1), the importance of water for pastoral communities and hence their climate sensitivity is likely to remain high.

A potential game changer could be the vast aquifers discovered in Turkana in September 2013. The replenishing rates of about 1.2 billion cubic metres per year would be more than enough to supply the entire county with water (Guardian, 2013). The aquifer did not come up in our interviews with community members. Josphat Nanok, governor of Turkana County, only stressed the need to develop the aquifer at the county level. In 2013 the Kenyan government in cooperation with UNESCO launched a countrywide groundwater mapping programme. As part of this mapping, the French company Radar Technologies International (RTI) 


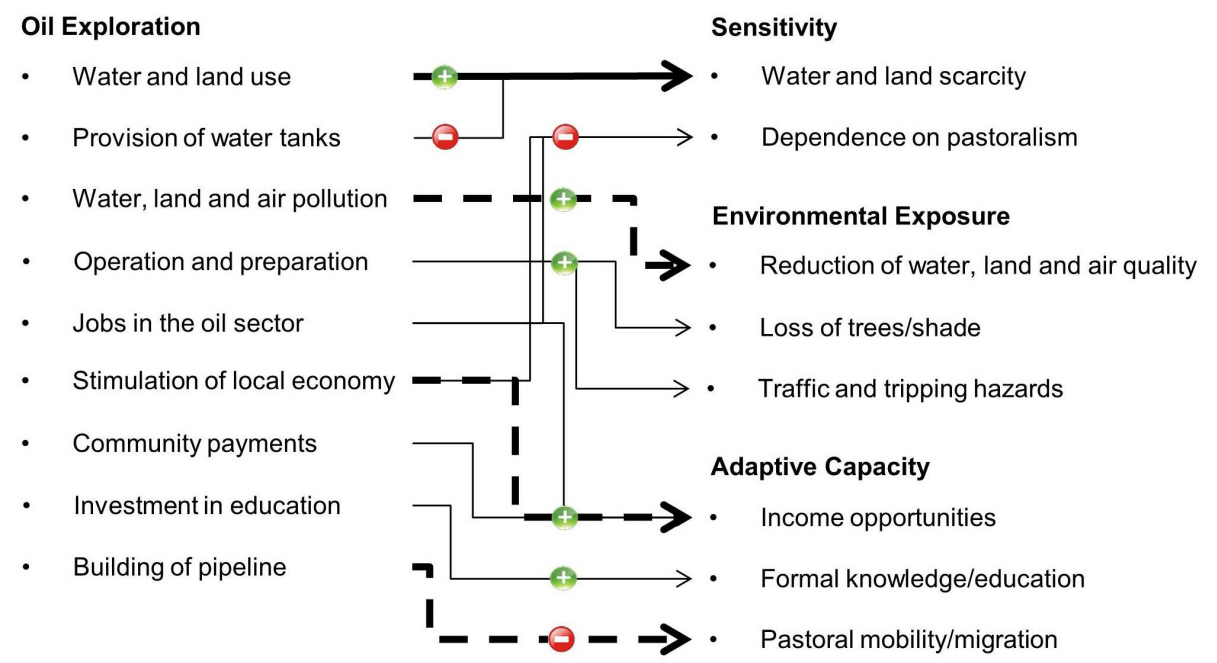

contributes to/creates $\oplus \quad$ reduces $\Theta \quad$ major effects in bold likely future effects dashed

Figure 3. Effects of oil exploration on vulnerability of pastoral communities.

announced that they had found " 66 trillion gallons of potable water" (Radar Technologies International, 2015) in Turkana. However, apart from a few boreholes drilled in northern Kenya, the process of the aquifer development has been slow and the impact limited (Guardian, 2015).

\subsubsection{Exposure}

Globally the burning of fossil fuels, including oil, is a major driver of climate change (Armaroli and Balzani, 2011). But the oil exploration in Turkana, at least so far, increases the climate exposure for the pastoral communities to a negligible extent. However, the oil exploration in Turkana exposes the communities to environmental changes, which in turn interact with changes in temperature and rainfall. Exposure to pollution of water, land and air is a major concern (Fig. 3). It has long been known that oil spills on land can "pose long term threats to groundwater quality" (Duffy et al., 1980). Studies conducted in Nigeria show that oil extraction can have detrimental effects on the environment and local populations, especially where environmental regulations are lacking or are not enforced, like in Kenya (for Nigeria see Linden and Palsson, 2013; Iwegbue, 2007; Orisakwe, 2009). Apart from the risk of contamination of drinking water (Owamah et al., 2013), for example by so-called non-aqueous-phase liquids, there is the possibility of inter-aquifer leakage. This term describes the process in which pumping causes (contaminated) ground water from another aquifer to enter the one being pumped (EPA, 1993). While the pollution of aquifers by oil is an environmental risk, it is beyond the scope of this study to assess this issue in detail. The respondents did not mention the pollution of water, possibly because they are not noticeable yet as the exploration in Turkana only started in 2012. In addition to water, land could be polluted for instance by the dumping of oil wastes without proper sealing and treatment (Khaitan et al., 2006; da Silva et al., 2013). But again, the pollution of land did not feature strongly in the responses of the communities.

In its national environmental policy, the Government of Kenya (2013, p. 40) recognises that "Kenya is vulnerable to illegal dumping of obsolete and banned toxic and hazardous substances". In response, the government stated in 2013 that it will develop a national policy on toxic and hazardous substances (ibid). However, to the authors' knowledge, this has not happened yet.

The community members reported several smaller changes in their environment related to the oil operation and preparation for it. Pastoralists from Lopii and Nakukulas mentioned that the noise and vibrations caused by the drilling disturb and scare the livestock. Community members claimed that some of their smaller livestock were injured by the wires that Tullow has set up. The research team observed that these wires run about 10 to $20 \mathrm{~cm}$ above the ground for several hundred metres. As they are often hidden by bushes, it is plausible that pastoralists see the wires as a tripping hazard for them and their livestock. Another reported change in the environment is black smoke coming from the oil exploration sites. Several community members in Nakukulas stated that they were afraid of the smoke since they were not used to it. And while the Turkana are used to cars, a few pastoralists reported that more livestock has been injured or killed in road accidents since the oil exploration started. Indeed, the increased traffic with jeeps, trucks and movement of heavy machinery related to the oil exploration was noticeable. Several pastoralists from Nakukulas complained that Tullow had cut down several trees and therefore shade was lacking to protect livestock from the heat. 


\subsubsection{Adaptive capacity}

The adaptive capacity is mainly determined by the knowledge, skills, resources and options the pastoralists have. A key adaptation strategy to lack of water and pasture is migration (Schilling et al., 2014). Some pastoralists claimed that the oil exploration sites had altered their migration routes, but the extent seems to be limited. This is likely to change when the extraction sites are connected to the refinery through a pipeline (see Tullow, 2014a, for the route of the pipeline). The degree of disruption caused by the pipeline will depend on how much of the pipeline will run underground. According to Tullow (2014a) this will "mostly" be the case. Railways and roads built as part of the LAPSSET project (see Sect. 2.1) are likely to affect pastoral migration in the future.

The research team observed envelopes being handed out by Tullow representatives to several community members in Lopii, who reported that Tullow has been distributing cash to the community. While this has other implications (see Sect. 3.2), the availability of financial resources generally increases the adaptive capacity of community members. Employment and stimulation of the local economy related to the oil extraction in Turkana offer further income opportunities. In an interview, James Lomenen, a member of parliament for Turkana South, described the discovery of oil as a promising "boost" for Kenya's economy. However, the low level of formal education is a disadvantage of the local communities when competing with others for economic and employment opportunities. Tullow has made efforts to contribute to education in Turkana. In Nakukulas, as part of its corporate social responsibility package, Tullow has built two classrooms and bought textbooks for the local primary school. In addition, the company has given scholarships to a few students to attend secondary school.

Improvements in infrastructure can also be related to Tullow's presence, and it has brought better transport links. Existing roads have been improved, new ones have been built, and the local airstrip has been restored to working order. However, most roads only connect Tullow sites to the major road. And the airstrip is only used by the oil company and government officials. Despite this, the assistant chief of Nakukulas acknowledged that this provision of services was, nevertheless, more than the government was offering, and better than nothing: "If it was left to me, I couldn't have brought this much development to my village."

In the mid- to long term the adaptive capacity of communities in Turkana will likely be affected by the process of devolution which Kenya has been undergoing since March 2013 (Vasquez, 2013). The World Bank (2015) has called it one of "the most rapid and ambitious devolution processes going on in the world". In an interview, James Lomenen described the idea of devolution to us as "bring[ing] services to the people". A key aim of the devolution is to reduce development imbalances between different regions within Kenya (Vasquez, 2013). As Turkana is the most marginalised county in the country, the county has received one of the highest financial transfers from the county devolution pool. In the financial year 2014/15, Turkana received KSH 9.1 billion, equal to about USD 86.8 million, and this amount has increased for the current financial year $(2015 / 2016)$ to KSH 10.2 billion (USD 97.3 million) (Nairobi News, 2015). However, these sums have not (yet) made a difference on the ground.

\subsection{Oil and conflict risk}

This section discusses the conflict risk associated with the oil exploration. The dimensions of both community-company and intercommunal conflict are addressed.

\subsubsection{Community-company conflict}

The communal perceptions of oil extraction and Tullow range from cautiously hopeful to hostile. In Lokwamosing and Lopii, community members have hopes and fears when it comes to and the impacts of oil. Some hope for jobs, water and education, while others, like the chief of Lokwamosing, have heard "where there is oil, there are conflicts". In Nakukulas, this is already the case. Tullow is increasingly viewed as a stressor or even an enemy. One woman describes the situation as being caught between two enemies: "on one side is the enemy [Pokot] and on the other is the oil company". The conflict between the community in Nakukulas and Tullow has resulted in community road blocks that disrupt the traffic to and from Tullow sites. The road blocks are usually resolved in exchange for water to the community and under heavy presence of security personnel. The security personnel consists of Kenya's administration police, the Kenya Police Reserve (KPR) and other Tullow security staff. While leaving Nakukulas, the research team of this study was also held up in a community road block, which was resolved without violence after about half an hour. Community members in Nakukulas also reported that "some Turkana" had "chased away" workers who were trying to fence off an area. Several participants of a mixed-gender focus group discussion in Nakukulas mentioned that they have "seen people" destroying the wires that Tullow installed. The majority of participants in the focus group discussion supported this action. Especially in comparison to the other two research locations, the atmosphere at the time of the research visits was tense. During the first research phase in October 2013 it took the local research assistants some effort to explain the purpose of the research and that the visitors were not associated with Tullow before the community would speak to the research team. Without being asked for it, the community members in Nakukulas started talking about Tullow and oil, which were the dominant topics. During the second research phase, the research team only interviewed the chief of Nakukulas because the aggravation of the community had reached a level which did not allow further interviews on this heated topic. 
Between the two research trips the level of violence between Nakukulas and Tullow had escalated. Newspapers reported of community demonstrations and storming of an oil site, including looting and destruction of property (Nation, 2013). Tullow had to suspend operations for several weeks because of the fragile security situation (Tullow, 2014c).

The causes of the community anger towards Tullow are driven not so much by the externalities of the oil exploitation but rather by the unmet expectations that the communities have for Tullow.

The expectations have to be understood against a wider background. There is a strong perception within the three communities and among pastoral groups in Turkana in general that they have been "forgotten" by the central government, who they believe does not care if they live or die (Schilling et al., 2012b; de Vries et al., 2006; Lesorogol, 2008; McCabe, 2004). This perception and the high development needs in Turkana create a hotbed for extremely high community expectations for the oil companies operating in the area. The communities see Tullow coming in with heavy and expensive machinery, building roads and drilling for water that the communities were unable to access. Table 1 shows the expectations of the communities in Lopii and Nakukulas (ranked by their importance) and how well they are met according to the communities.

By far, the most important issue was employment. "We want Tullow to give us jobs" was a recurring expectation articulated by community members in both Lopii and Lokwamosing. In Nakukulas, the community's expectation has already been replaced by frustration.

According to the county government act, $70 \%$ jobs from Tullow are meant for local Turkana and $30 \%$ for others. However this allocation is not being met. Community members themselves acknowledge that the locals are not qualified. They suggested that Tullow could offer apprenticeships to train them. Several respondents felt they are stereotyped as a community as being illiterate and ignorant pastoralists. The highest position a Turkana has at Tullow is that of a CLO, there are no Turkana in management positions, and the best job a young Turkana man can get is as a security guard (earning about KSH 18000 or USD 190 per month). According to villagers, Tullow even flies in drivers from Nairobi. This is a source of major resentment: "Employment from Tullow goes to people from Kitale. Leadership is not proactive to help us get work. They say we are not learned to get jobs, that we have not been to school. We don't know what kind of school these people in Kitale have! If we are not learned, can we not be given causal jobs?" Community members saw that conflict would be inevitable if things did not change. "We can only see a tense future with Tullow unless the government can do something good for us that will let us forget our precious treasures that have been taken from us."

Tullow has not released any recent numbers on employment and the company was not available for any interviews. In October 2013, a press release by Tullow claimed that "Tul-
Table 1. Community expectations and level of satisfaction.

\begin{tabular}{lll}
\hline Community expectations & \multicolumn{2}{c}{$\begin{array}{c}\text { Level of community } \\
\text { satisfaction }\end{array}$} \\
\cline { 2 - 3 } & Lopii & Nakukulas \\
\hline 1. Employment & very low & very low \\
2. Water & medium & very low \\
3. Land compensation & very low & low \\
4. Education & low & medium \\
5. Company payments & medium & low \\
6. Mitigation of inter- & very low & very low \\
pastoral conflicts & & \\
\hline
\end{tabular}

low employs over 800 people from the Turkana region out of the 1400 people currently employed on Tullow's Kenyan operations" (Tullow, 2013b). There are several newspaper reports and websites citing a more recent Tullow statement that "as at the end of August 2014, 2187 out of the 3619 staff employed by Tullow and its contractors came from Turkana" (Oilnews, 2014; Business Daily, 2014). The statement is, however, not available (anymore) on the Tullow website and it needs to be questioned whether the numbers are realistic, at least for the research area. According to the chiefs and community members in Nakukulas and Lopii, the direct employment of Turkana in the oil sector has been minimal. Numbers between 4 and 15 were given. Community members stated that the highest position a Turkana has at Tullow is as a CLO. The CLOs are the main communication channel between Tullow and the communities: the CLOs are supposed to listen to the communities' needs, concerns and complaints and to relay them back to Tullow; at the same time, they should inform the communities about the company's actions and plans. Another position mentioned was security guard. Overall, the oil industry is capital- rather than labour-intensive. Hence there is a low demand for unskilled labour. This is a fact that neither Tullow nor representatives of the Kenyan government have clearly told the communities.

Water is the next critical conflict issue. The three communities expect Tullow to give them water. To a limited extent, Tullow is doing this: drilling boreholes, setting up water tanks and filling them, according to an informal interview with a CLO, "on a regular basis". In addition, water points with pumps are set up in communities. However, the members of the Nakukulas community reported that Tullow only started to share the pumped water after ongoing and vocal complaints from the community. Further, Tullow is unlikely to meet the communities' expectations for water. One elder in Nakukulas stated, "We have only very small positive changes from Tullow since 2011. The water pump they gave us is not enough as it serves both livestock and community - one water source can't support everyone." Asked about the reasons for the community road blocks and attacks on Tullow, most interviewees responded "jobs" and "water". The latter 
is likely to become more prominent in the future, when almost inevitable high usage and pollution of groundwater will become noticeable.

Land is the third critical conflict driver. Traditionally Turkana is communal land, which means there is no individual ownership of the land. However, the government of Kenya has given Tullow and Oil Africa licence to explore oil reserves in Turkana. The communities in Lopii and especially in Nakukulas perceive Tullow has an actor who comes and takes their land without proper community consultation or compensation for taken land. One woman from Nakukulas states, "Of our two enemies [Pokot and Tullow], we fear the Pokot the most. Tullow will only take our land, but the Pokot will take everything and kill us." Several community members mentioned that Nakukulas has received some compensation from Tullow. One elder named an amount of KSH 2.2 million (USD 24000 ). In Lopii the research team observed Tullow distributing one-off cash payments to households. The immediate response in the community was very positive. "Today is like a festival" stated one woman. But the payments are likely to further increase community expectations for more payments, especially because the compensation for the lost resources is seen as insufficient. The following statement from Nakukulas summarises the view on monetary compensation: "[These] are good but too small to address the negative impacts of the companies. They are not enough for us. We cannot consider the small gestures as compensation for the amount of land and animals they have taken from us." Another elder added, "Our main concern is the land they [Tullow] have taken from us." The communities have not received any compensation from the Kenyan government. Once the actual exploitation of the oil reserves starts (see Sect. 2.1), the Kenyan constitution demands that the profits be shared between the national government (receiving $70 \%$ ), the county government (receiving $20 \%$ ) and the local communities (receiving 10\%) (Republic of Kenya, 2010). The issue of revenue sharing is already causing disagreements between the different levels of government (Star, 2012).

The demand for education was less of a conflict driver in Lopii and Nakukulas, although still present. Tullow has made efforts to improve the level of education in Turkana. According to Tullow, 100 (out of 11000 ) applicants were selected for the 2013/2014 scholarship programme, which supports postgraduate degrees, technical training and vocational studies (Tullow, 2013a, b). In Nakukulas the company has built two new classrooms, bought textbooks and gave a few students scholarship.

Some community members in Nakukulas expressed hopes that Tullow could improve the security situation in the region. But an elder noted, "Tullow is not concentrating on conflict between Turkana and Pokot. Pokot always come and raid us. Tullow does not even want to mitigate or to respond." (See also Sect. 3.2.2.)
The conceptual framework, developed in Sect. 2.3, is useful in understanding the interactions between the communities and Tullow. The communities in Lopii and especially Lokwamosing had not interacted with Tullow much. But in Nakukulas a motivation to choose a conflicting path with Tullow could be observed. In the first research phase, the assistant chief of Nakukulas explained that if community members have a complaint, for example over the cutting of trees, an animal hit by a Tullow vehicle, or about a water issue, the elders come together to talk to the village chief, who then takes the issue to the district commissioner and finally to Tullow. The majority of respondents expressed dissatisfaction with this very indirect way and the response to some of the complaints. CLOs offer a more direct way of communication, but Tullow had stopped sending CLOs to Nakukulas, likely because of the tense security situation associated with a series of community road blocks and an attack on an oil site. This shows that, after the Nakukulas community had chosen a conflicting path, Tullow refrained from investing into a cooperative path (Fig. 2). This, in turn, is negatively perceived by the community. The assistant chief states, "The CLOs used to come to talk to and even stay with community to try to understand their views before extraction started but [they] stopped coming last year [2013]." "Tullow is like a rock. It does not listen," stated one elder. The broken communication with Tullow is likely to increase the risk of community members resorting to force to achieve their aims. Table 2 lists the main actors and their motivation and capability.

A long history of violent conflicts with other groups has provided the Turkana communities in the research area with the skills, knowledge and arms to execute violent attacks. Tullow is motivated to ensure smooth operations. The company has the financial means to set up their own security forces, but these imply costs, especially when conflicts are escalating.

Despite likely contradictions with Kenya's climate goals (Sawa, 2015), the national government supports Tullow because of the expected revenues. There is a risk that the oil profits do not trickle down through the different levels of government to the local communities, especially because corruption (rank 145 of 175 countries) and patronage along political and ethnic lines is already a widespread problem in Kenya (Transparency International, 2014; Carrier and Kochore, 2014). Member of parliament James Lomenen notes, "Oil is not the problem - it is how it is done that is the issue." The local government, mainly represented by the village chiefs, is in a difficult position. On the one hand, the chiefs have to follow the national direction and support the oil exploration. On the other hand, they understand their communities' frustration with the effects caused by oil exploration. 
Table 2. Motivation and capability of key actors.

\begin{tabular}{|c|c|c|c|c|c|c|}
\hline & \multirow[t]{2}{*}{ Turkana communities } & \multirow[t]{2}{*}{ Tullow } & \multicolumn{3}{|c|}{ Government } & \multirow[t]{2}{*}{ Pokot } \\
\hline & & & National & County & Local & \\
\hline Motivation & $\begin{array}{l}\text { - Jobs with Tullow } \\
\text { - Financial compensation for } \\
\text { land } \\
\text { - Improved water infrastructure } \\
\text { - Improvements in schools and } \\
\text { education } \\
\text { - Avoiding of externalities of oil } \\
\text { exploration } \\
\text { - Increase in local economy } \\
\text { - Decrease in violent conflicts }\end{array}$ & $\begin{array}{l}\text { - Smooth } \\
\text { operations } \\
\text { to explore } \\
\text { oil } \\
\text { resources } \\
\text { - Avoiding of } \\
\text { disruption } \\
\text { and } \\
\text { additional } \\
\text { costs } \\
\text { - Decrease in } \\
\text { violent } \\
\text { conflicts }\end{array}$ & $\begin{array}{l}\text { - Smooth } \\
\text { and uninter- } \\
\text { rupted oil } \\
\text { explorations } \\
\text { - Revenues } \\
\text { from oil } \\
\text { exploration and } \\
\text { potential } \\
\text { exploitation } \\
\text { - Decrease in } \\
\text { violent conflicts }\end{array}$ & $\begin{array}{l}\text { - Revenues from oil } \\
\text { exploration and } \\
\text { potential } \\
\text { exploitation } \\
\text { - Decrease in } \\
\text { violent conflicts }\end{array}$ & $\begin{array}{l}\text { - Financial benefits } \\
\text { and infrastructure } \\
\text { improvements from } \\
\text { oil exploration and } \\
\text { potential exploitation } \\
\text { - Increase in local } \\
\text { economy } \\
\text { - Decrease in violent } \\
\text { conflicts }\end{array}$ & $\begin{array}{l}\text { - Financial compensation } \\
\text { for land claimed by Pokot } \\
\text { - Jobs with Tullow }\end{array}$ \\
\hline Capability & $\begin{array}{l}\text { - Local knowledge of } \\
\text { communities and area } \\
\text { - Weapons/ammunition } \\
\text { - Manpower } \\
\text { - Experience in attacks }\end{array}$ & $\begin{array}{l}\text { - Financial } \\
\text { means } \\
\text { - Relations to } \\
\text { and support } \\
\text { of national } \\
\text { government }\end{array}$ & $\begin{array}{l}\text { - Highest } \\
\text { authority } \\
\text { - Contract } \\
\text { party with } \\
\text { Tullow }\end{array}$ & $\begin{array}{l}\text { - Contact to local } \\
\text { and national } \\
\text { government }\end{array}$ & $\begin{array}{l}\text { - Contact to local } \\
\text { communities and } \\
\text { county government }\end{array}$ & $\begin{array}{l}\text { - Local knowledge of } \\
\text { communities and area } \\
\text { - Weapons/ammunition } \\
\text { - Manpower } \\
\text { - Experience in attacks }\end{array}$ \\
\hline
\end{tabular}

The assistant chief of Nakukulas warns, "If Tullow will not work hand in hand with the community and administration, the direction will be very, very hard for them." An elder concluded, "We do not see a positive future relationship with Tullow." Against this background, the risk of an escalation of conflict between the community of Nakukulas and Tullow is significant. Lopii and Lokwamosing could follow that path. In addition, the exploration of oil has implications for intercommunal conflicts in the region.

\subsubsection{Intercommunal conflict and oil}

The research area is heavily affected by intercommunal conflicts and raids (see Fig. 1 in Sect. 2.1). Between 2006 and 2009 the average number of 71 raids per year (6 raids per month) reflects the high level of insecurity expressed by the interviewees. On average two people died per raid over the 4 years considered (TUPADO, 2011). The highest intensity of raiding is found in the border region between the Turkana and Pokot (Fig. 1). Lokwamosing is part of this raiding hotspot, while Nakukulas and Lopii fall within the second highest raid category. The distribution of raids across Turkana shows a similar pattern to the one identified by Ember et al. (2012), with two differences. First, according to the TUPADO conflict records, no raids occurred in the northeast part of Turkana, while Ember et al. (2012) report between 11 and 14 raids here, although over a longer period of time (1998 to 2009). Second, Ember et al. (2012) find a significantly smaller total number of raids. For instance, the darkred area in Fig. 1 indicates more than 40 raids, while Ember et al. (2012) find between zero and a maximum of 10 raids in the same areas.
Tullow has dealt with this high level of insecurity by recruiting officers for the Kenya Police Reserve (KPR) from the wider region to protect their oil sites and transportation routes. The KPR officers are community members who are a given a gun, some ammunition, a uniform and some allowance by the government of Kenya to protect their community (Schilling et al., 2012b). A member of parliament stated in an interview that $1000 \mathrm{KPR}$ officers have been assigned to guard oil operations. Tullow informally gave a much smaller figure of 200. Regardless of the exact number, members of all three research locations have indicated that, on the one hand, the increased presence of KPR officers has improved the security situation where the oil exploitation is taking place. Several community members, for example in Lokwamosing, reported that the raiding by the Pokot had decreased. "The home guards are patrolling," notes one community member. On the other hand, insecurity in other areas such as the raiding hotspots along the Turkana-Pokot border was reported to have increased due to a lack of KPR officers.

In addition to oil affecting the distribution of security forces in the region, there is a concern that it is increasing the value of land and hence the Pokot's interest in it (Table 2). Disputed territory is already a driver of the TurkanaPokot conflict (Schilling et al., 2012b; Adem et al., 2012; Vasquez, 2013). However, it is too early to say to what extent oil exploration will affect land rights and prices. But the oil exploration could further weaken the already weak social contract between the pastoral communities and the central government. A few community members in Nakukulas blamed the government in Nairobi for the situation with Tullow. One woman summarised, "We don't know fully of the oil company's benefits to us. Maybe it will be of benefit to 
our children. But now we have no power to change anything. This is something that the government has brought to us."

Employment with Tullow could also become a source of conflict between communities. The members of a group consisting of local NGO representatives and local businessmen working on natural resources in Turkana South stated that people from Turkana East do not want people from Turkana South to take "their" jobs and vice versa. However, the community interviews in Nakukulas, Lopii and Lokwamosing gave little evidence for strong grievances over employment among communities in Turkana.

\subsection{Synthesis of oil, conflict, vulnerability, and climate change}

Figure 4 combines the results of Sects. 3.1 and 3.2 to place them within the context of the big picture. The oil exploration creates high expectations among the communities for employment, water provision and general development (education, infrastructure, financial benefits). In the communities' view, the expectations are not met, which in turn can be seen as the major driver for the conflicts between the communities and Tullow. It is possible that the longer the community expectations are not met, the stronger this conflict driver will be come.

Oil exploration (and later exploitation) needs significant amounts of groundwater which the communities depend on. Other externalities (loss of land, disturbance of livestock, and disruption of migration routes) and pollution of water and soil will likely become a source of conflict, but at the time of the research these externalities were less noticeable (hence a thinner line between externalities and conflict). The pollution and externalities associated with oil contribute to the communities' vulnerability through an increase in their exposure to environmental changes (reduction and degradation of water and land resources, loss of trees) and a potential reduction in their adaptive capacity through limitation of mobility (especially once the pipeline is built).

But the oil exploration can also improve the communities' adaptive capacity and hence reduce vulnerability through offering of development opportunities (Fig. 4). Direct employment with Tullow and indirect income opportunities related to the growth of local hubs such as Lokichar (Fig. 1) can strengthen the adaptive capacity of communities while reducing their dependence on pastoralism and therefore their sensitivity to climatic changes.

There were indications that oil exploration affects the Turkana-Pokot conflict through an alteration of security presence and potential greed-driven motivations over territory and oil compensation, but this finding is less reliable than the others.

The oil exploration and especially the exploitation later on will produce greenhouse gases, which in turn drive climate change (left side of Fig. 4). But, in the context of global emissions, this has a marginal effect for the local situation

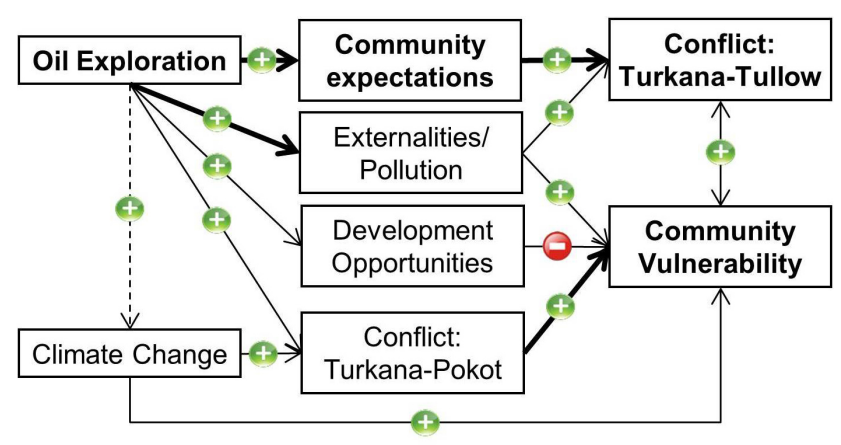

contributes to/creates

reduces

major effects/elements in bold

Figure 4. Key interactions between oil, conflict, vulnerability, and climate change.

(hence a dashed line). However, previous studies have shown that climate change aggravates the existing conflicts between the Turkana and Pokot (Scheffran et al., 2014; Omolo, 2010; Schilling et al., 2014; Ide et al., 2014). The conflicts in turn contribute strongly to community vulnerability because they lead to loss of human lives and livestock, spread insecurity and result in inefficient use of pasture (Schilling et al., 2012b). Positive mutual feedback between communitycompany conflict and vulnerability indicates that a vicious cycle or a "spiral of violence" (Scheffran et al., 2014) could start or escalate. Vulnerability increases the risk that communities resort to violence and conflicts, while these in turn contribute to vulnerability.

Overall, the identified conflict risk is in line with a previous study. However, Johannes et al. (2014) place a stronger emphasis on land as a key conflict driver, while the present study suggests that the conflicts between the communities and Tullow are mostly driven by unfulfilled community expectations for water and employment.

\section{Conclusions}

The communities in Turkana South face significant challenges of violent intercommunal conflict, climate change, and political and economic marginalisation. Devolution is moving forward. Now oil enters the scene. The current extraction and later exploitation of oil brings new economic opportunities and infrastructure improvements to Turkana. Both are likely to reduce the vulnerability of communities to climate change. However, significant water usage and pollution of soil and water related to the oil extraction are likely to exceed these effects. So far the externalities of the oil exploration are much less of a driver of the conflicts between the community in Nakukulas and Tullow as compared to the unfulfilled community expectations. The Kenyan government has failed to provide Turkana with basic services, including education, infrastructure and, most of all, security. Now the communities see a new potent actor entering the region 
who has the capability to drill for water, build roads and accumulate security personnel. This has led the communities to transfer their expectations for development and security away from the government of Kenya and onto Tullow. It is, however not, the company's responsibility to make up for government failure. However, Tullow is facing these expectations whether they are justified or not. Tullow has responded with some provision of water, financial compensation and education resources, but there is still a strong feeling among the communities that they only experience the externalities of the "oil rush" while others outside of Turkana get the jobs, revenues and prosperity. Unmet community expectations, especially for employment and provision of water, have resulted in community road blocks, destruction of company property and attacks on oil sites. To prevent a further escalation of violence which will be detrimental to all parties involved, significant changes are needed that are driven by different actors.

In conjunction with the ongoing process of devolution, the government of Kenya needs to ensure a fair and transparent sharing of oil revenues between the different levels of government and the local communities, who need to be included more strongly. The county government needs to use the financial assets received through devolution and the oil revenues to finally make up for its failure in Turkana. This implies significant investments into education, health services, and water and transport infrastructure. In particular, the development of the significant aquifers found in Turkana needs to be prioritised and accelerated to improve the water availability and access for the communities. The oil pipelines, roads and railways associated with the LAPSSET project need to be planned and built with sensitivity to existing pastoral migration routes and grazing land.

The issue of land rights has to be addressed to prevent the communities from losing their land without proper compensation. Strong environmental regulations and especially their enforcement are needed to prevent oil pollution of water and soil. The county and local government need to offer communication channels for local communities to enable them to express their concerns and requests in a more effective and direct way. Finally, the issue of insecurity and violent conflict needs to be addressed through intercommunal peace meetings, especially between the Turkana and Pokot.

Tullow and any oil company operating in Turkana are well advised to closely communicate with the local communities to inform them about the operations, get their feedback and, in particular, manage their expectations. Community liaison officers (CLOs) are a promising approach. While it needs to be acknowledged that the demand for unskilled labour in the oil industry is limited, integration of Turkana into the company's workforce will be a positive sign for the communities. To be able to increase the share of Turkana employees, it is important to offer training possibilities in which community members can acquire skills needed in the oil industry. Tullow should ensure that risks of environmental pollution are minimised. Water needs to be shared with the community in a way that is reliable and transparent but also sustainable.

The communities need to reduce their expectations for employment at Tullow and redirect their legitimate demands for development and security back to the government of Kenya. Frustration with Tullow should be expressed in a non-violent manner, for example through the chiefs or CLOs. If every actor, particularly the government of Kenya and Tullow, takes these recommendations seriously, then there is a real chance that Turkana and Kenya overall can benefit from the oil. Unfortunately, the more likely scenario is that oil will exacerbate the existing marginalisation and discrimination of pastoral communities, which in turn is likely to fuel more conflict.

For further studies it is promising to continue to explore the nexus of oil, conflict and climate change, including also urban centres of Turkana, and particularly with respect to the evolving issues of environmental pollution, the building of the oil pipeline (including LAPSSET) and potential impacts on inter- and intra-communal conflict.

Acknowledgements. The authors dedicate this publication to their dear friend Beth Njeri Njiru, who passed away so early and unexpectedly. The authors thank the communities of Lokwamosing, Lopii and Nakukulas as well as every person who volunteered information for this study. The authors appreciate the helpful comments of the reviewers. The field research was made possible by International Alert. The overall work is supported through the Cluster of Excellence "Integrated Climate System Analysis and Prediction - CliSAP", Universität Hamburg, funded by the German Science Foundation (DFG).

Edited by: P. M. Link

\section{References}

Adem, T. A., Ember, C. R., Skoggard, I., Jones, E. C., and Faas, A. J.: Dangerous geography: Spatial distribution of livestock raiding in northwestern Kenya, Ethnology, 51, 1-29, 2012.

Africa Oil: Current activities - Kenya, http://www.africaoilcorp. com/s/current-activities.asp/, last access: 9 October 2015.

Aghalino, S. O.: Oil exploitation and the accentuation of intergroup conflicts in the Niger Delta, Nigeria, J. Human Ecol., 28, 153159, 2009.

Allen, L., Cohen, M., Abelson, D., and Miller, B.: Fossil fuels and water quality, in: The world's water, Vol. 7, edited by: Gleick, P., Island Press/Center for Resource Economics, Washington, D.C., 73-96, 2011.

Amundsen, I.: Drowning in oil angola's institutions and the "resource curse", Comparative Politics, 46, 169-189, 2014.

Anderson, D. M. and Browne, A. J.: The politics of oil in eastern Africa, J. East. Afr. Stud., 5, 369-410, doi:10.1080/17531055.2011.573187, 2011.

Anifowose, B., Lawler, D. M., van der Horst, D., and Chapman, L.: Attacks on oil transport pipelines in Nigeria: A quantitative 
exploration and possible explanation of observed patterns, Appl. Geogr., 32, 636-651, doi:10.1016/j.apgeog.2011.07.012, 2012.

Armaroli, N. and Balzani, V.: The legacy of fossil fuels, Chem.Asian J., 6, 768-784, doi:10.1002/asia.201000797, 2011.

Business Daily: Turkana locals take lion's share of tullow jobs, http://www.businessdailyafrica.com/ Turkana-locals-take-lion-s-share-of-Tullow-jobs/-/539552/ 2469114/-/4fynp0/-/index.html (last access: 2 November 2015), 2014.

Cairn: Oil and gas exploration and production life cycle, http://www.cairnenergy.com/index.asp?pageid=554, last access: 1 April 2015.

Carrier, N. and Kochore, H. H.: Navigating ethnicity and electoral politics in northern Kenya: The case of the 2013 election, J. East. Afr. Stud., 8, 135-152, doi:10.1080/17531055.2013.871181, 2014.

CEWARN: Cewarn country updates: September-December 2009, CEWARN (Conflict Early Warning and Response Mechanism), Addis Ababa, 2010.

Chavunduka, C. and Bromley, D.: Climate, carbon, civil war and flexible boundaries: Sudan's contested landscape, Land Use Policy, 28, 907-916, 2011.

Daily Nation: Tullow to slash budget for oil search in Kenya, http://www.nation.co.ke/business/ Tullow-to-slash-budget-for-oil-search-in-Kenya/-/996/ 2620918/-/b13udqz/-/index.html, last access: 1 April 2015.

da Silva, L. J., Oliveira, F. J. S., and Pessoa de Franca, F.: Oil waste management through large scale landfarming: A case study, Int. J. Environ. Waste Manage., 11, 233-243, 2013.

Devereux, S.: Better marginalised than incorporated - pastoralist livelihoods in somali region, ethiopia, EUR J DEV RES, 22, 678695, 2010.

de Vries, D., Leslie, P., and McCabe, J.: Livestock acquisitions dynamics in nomadic pastoralist herd demography: A case study among ngisonyoka herders of south turkana, kenya, Hum. Ecol., 34, 1-25, doi:10.1007/s10745-005-9000-2, 2006.

Duffy, J. J., Peake, E., and Mohtadi, M. F.: Oil spills on land as potential sources of groundwater contamination, Environ. Int., 3, 107-120, doi:10.1016/0160-4120(80)90045-8, 1980.

Ember, C. R., Abate, A. T., Skoggard, I., and Jones, E. C.: Livestock raiding and rainfall variability in northwestern Kenya, Civil Wars, 14, 159-181, doi:10.1080/13698249.2012.679497, 2012.

EPA: Well ahead: A guide for small communities, United States Environmental Protection Agency, Washington, D.C., 1993.

Financial Times: Kenya's target for initial oil production faces obstacles, http://www.ft.com/intl/cms/ s/0/692e4bec-603f-11e4-88d1-00144feabdc0.html\# axzz3W4AZzn4F (last access: 1 April 2015), 2014.

Financial Times: Falling crude price hits prospects for East Africa, http://www.ft.com/intl/cms/s/0/ 0961f6a2-b13c-11e4-831b-00144feab7de.html\# axzz3W4AZzn4F, last access: 1 April 2015.

Government of Kenya: National policy for the sustainable development of arid and semi arid lands, Government of Kenya, Nairobi, 2007.

Government of Kenya: Kenya discovers oil, president Kibaki announces, http://www.statehousekenya.go.ke/news/march2012/ 2012260301.htm, last access: 2 November 2012.
Government of Kenya: National environmental policy, 2013, Government of Kenya, Nairobi, 2013.

Guardian: Kenya water discovery brings hope for drought relief in rural north, http://www.theguardian.com/global-development/ 2013/sep/11/kenya-water-discovery-drought-relief (last access: 9 October 2015), 2013.

Guardian: Kenyans frustrated by drip, drip approach to search for water, http://www.theguardian.com/global-development/ 2015/jan/15/kenya-water-turkana-aquifer-kakuma, last access: 9 October 2015.

Hammond, J. L.: The resource curse and oil revenues in Angola and Venezuela, Sci. Soc., 75, 348-378, 2011.

Ide, T., Schilling, J., Link, J. S. A., Scheffran, J., Ngaruiya, G., and Weinzierl, T.: On exposure, vulnerability and violence: Spatial distribution of risk factors for climate change and violent conflict across Kenya and Uganda, Polit. Geogr., 43, 68-81, 2014.

Idemudia, U.: The resource curse and the decentralization of oil revenue: The case of Nigeria, J. Clean. Prod., 35, 183-193, doi:10.1016/j.jclepro.2012.05.046, 2012.

Ikelegbe, A.: Civil society, oil and conflict in the niger delta region of nigeria: Ramifications of civil society for a regional resource struggle, J. Mod. Afr. Stud., 39, 437-469, 2001.

International Alert: Harnessing oil for peace and development in Uganda, International Alert, London, 2009.

IPCC: Climate change 2013: The physical science basis, Cambridge University Press, Cambridge, 2013.

IPCC: Climate change 2014: Impacts, adaptation and vulnerability, Cambridge University Press, Cambridge, 2014.

Iwegbue, C. M. A.: Distribution of heavy metals in sediments and surface water of crude oil impacted area in the Niger Delta, Nigeria, Pakistan J. Scient. Indust. Res., 50, 178-183, 2007.

Johannes, E. M., Zulu, L. C., and Kalipeni, E.: Oil discovery in Turkana county, Kenya: A source of conflict or development?, Afr. Geogr. Rev., 34, 1-23, doi:10.1080/19376812.2014.884466, 2014.

Kenya Open Data: Poverty, https://www.opendata.go.ke/ Poverty/Poverty-Rate-by-District/i5bp-z9aq (last access: 13 March 2015), 2011a.

Kenya Open Data: School attendance, https://www.opendata.go.ke/Counties/

2009-Census-Vol-II-Table-1-Population-3-years-and-/ jkkd-epmw (last access: 13 March 2015), 2011 b.

Kenya Open Data: Water points Turkana, https: //www.opendata.go.ke/Water-and-Sanitation/

Turkana-County-Safe-Vs-Unsafe-Water-Source-points/ fk7v-yhvz, (last access: 13 March 2015), 2014a.

Kenya Open Data: Population, https: //www.opendata.go.ke/Population/

Census-Volume-1-Question-1-Population-Households-a/ wd27-eki2, (last access: 13 March 2015), 2014b.

Khaitan, S., Kalainesan, S., Erickson, L. E., Kulakow, P., Martin, S., Karthikeyan, R., Hutchinson, S. L. L., Davis, L. C., Illangasekare, T. H., and Ng'oma, C.: Remediation of sites contaminated by oil refinery operations, Environ. Progr., 25, 20-31, doi:10.1002/ep.10083, 2006.

Koocheki, A. and Gliessman, S. R.: Pastoral nomadism, a sustainable system for grazing land management in arid areas, J. Sustain. Agr., 25, 113-131, doi:10.1300/J064v25n04_09, 2005. 
LAPSSET: Kenya and Uganda strike deal on route for sh400bn oil pipeline, http://www.lapsset.go.ke/newscast/pages\#, last access: 9 October 2015.

Lesorogol, C. K.: Land privatization and pastoralist well-being in Kenya, Develop. Change, 39, 309-331, doi:10.1111/j.14677660.2007.00481.x, 2008.

Levine, S.: An unromantic look at pastoralism in karamoja: How hard-hearted economics shows that pastoral systems remain the solution, and not the problem, Nomadic Peoples, 14, 147-153, 2010.

Linden, O. and Palsson, J.: Oil contamination in ogoniland, Niger Delta, Ambio, 42, 685-701, doi:10.1007/s13280-013-0412-8, 2013.

McCabe, J. T.: Cattle bring us to our enemies: Turkana ecology, politics, and raiding in a disequilibrium system, University of Michigan Press, Ann Arbor, 2004.

McSweeney, C., New, M., and Lizcano, G.: Undp climate change country profiles - Kenya, http://www.geog.ox.ac.uk/research/ climate/projects/undp-cp/UNDP_reports/Kenya/Kenya.lowres. report.pdf (last access: 3 March 2015), 2012.

Mkutu, K. A.: Small arms and light weapons among pastoral groups in the Kenya-Uganda border area, African Affairs, 106, 47-70, 2006.

Mkutu, K. A.: Complexities of livestock raiding in Karamoja, Nomadic Peoples, 14, 87-105, 2010.

Mude, A., Barrett, C. B., Carter, M. R., Chantarat, S., Ikegami, M., and McPeak, J.: Index based livestock insurance for northern Kenya's arid and semi-arid lands: The Marsabit pilot, International Livestock Research Institute, Nairobi, 2009.

Nairobi News: Nairobi and Turkana to get biggest share of county cash, http://nairobinews.nation.co.ke/ nairobi-and-turkana-to-get-biggest-share-of-county-cash/, last access: 9 October 2015.

Nation: Turkana MP under probe over riots against tullow oil firm, http://mobile.nation.co.ke/News/ MP-under-probe-over-Turkana-riots/-/1950946/2053848/-/ format/xhtml/-/pd78haz/-/index.html, last access: 26 November 2013 .

Obi, C. I.: Transnationalism, africa's 'resource curse' and 'contested sovereignties': The struggle for Nigeria's Niger Delta, Africa and international relations in the 21st century, edited by: Cornelissen, S., Cheru, F., and Shaw, T. M., Palgrave Macmillan, New York, 147-161, 2012.

Obioha, E. E.: Climate variability, environment change and food security nexus in Nigeria, J. Human Ecol., 26, 107-121, 2009.

Oilnews: Tullow kenya conducts stakeholder engagement in Elgeyo Marakwet and Baringo, http://www.oilnewskenya.com/?p=1835 (last access: 29 June 2015), 2014.

Omolo, N. A.: Gender and climate change-induced conflict in pastoral communities: Case study of Turkana in northwestern kenya, Afr. J. Conflict Resolut., 10, 81-102, 2010.

Opiyo, F., Wasonga, O., and Nyangito, M.: Measuring household vulnerability to climate-induced stresses in pastoral rangelands of Kenya: Implications for resilience programming, Pastoralism, 4, 1-15, doi:10.1186/s13570-014-0010-9, 2014.

Opiyo, F., Wasonga, O., Nyangito, M., Schilling, J., and Munang, R.: Drought adaptation and coping strategies among the Turkana pastoralists of northern Kenya, Int. J. Disast. Risk Sci., 6, 295309, doi:10.1007/s13753-015-0063-4, 2015.
Orisakwe, O. E.: Environmental pollution and blood lead levels in nigeria: Who is unexposed?, Int. J. Occup. Environ. Health, 15, 315-317, 2009.

Osuji, L. C., Adesiyan, S. O., and Obute, G. C.: Post-impact assessment of oil pollution in agbada west plain of niger delta, nigeria: Field reconnaissance and total extractable hydrocarbon content, Chem. Biodivers., 1, 1569-1578, doi:10.1002/cbdv.200490117, 2004.

Owamah, I. H., Asiagwu, A. K., Egboh, S. H. O., and Phil-Usiayo, S.: Drinking water quality at isoko north communities of the Niger Delta region, Nigeria, Toxicol. Environ. Chem., 95, 11161128, doi:10.1080/02772248.2013.847939, 2013.

Pantuliano, S.: Oil, land and conflict: The decline of misseriyya pastoralism in sudan, Rev. Afr. Polit. Econ., 37, 7-23, doi:10.1080/03056241003637847, 2010.

Pavanello, S.: Pastoralists' vulnerability in the Horn of Africa exploring political marginalization, donors' policies, and crossborder issues, Overseas Development Institute, London, 2009.

President of Kenya: Lappset project, http://www.president.go.ke/ projects/lappset-projects/, last access: 9 October 2015.

Ptacek, C., Price, W., Smith, J. L., Logsdon, M., and McCandless, R.: Land-use practices and changes - mining and petroleum production, in: Threats to water availability in Canada, edited by: National Water Research Institute, and Canada, M. S. O., National Water Research Institute, Burlington, 67-76, 2004.

Radar Technologies International: RTI's list of accomplishment, http://www.rtiexploration.com/, last access: 9 October 2015.

Republic of Kenya: The constitution of Kenya, https://www. kenyaembassy.com/pdfs/The_Constitution_of_Kenya.pdf (last access: 14 April 2014), 2010.

Sala-i-Martin, X. and Subramanian, A.: Addressing the natural resource curse: An illustration from Nigeria, J. Afr. Econ., 22, 570615, doi:10.1093/jae/ejs033, 2013.

Sawa, P.: Oil exploitation contradicts Kenya's climate goals, legislator warns, http://www.trust.org/item/20140526131230-mdjnu/, last access: 21 May 2015.

Scheffran, J., Link, P. M., and Schilling, J.: Theories and models of climate-security interaction: Framework and application to a climate hot spot in North Africa, in: Climate change, human security and violent conflict: Challenges for societal stability, Hexagon series on human and environment security and peace, edited by: Scheffran, J., Brzoska, M., Brauch, H. G., Link, P. M., and Schilling, J., Springer, Berlin, 91-131, 2012.

Scheffran, J., Ide, T., and Schilling, J.: Violent climate or climate of violence? Concepts and relations with focus on Kenya and Sudan, Int. J. Human Rights, 18, 369-390, doi:10.1080/13642987.2014.914722, 2014.

Schilling, J., Freier, K. P., Hertig, E., and Scheffran, J.: Climate change, vulnerability and adaptation in North Africa with focus on morocco, Agr. Ecosyst. Environ., 156, 12-26, doi:10.1016/j.agee.2012.04.021, 2012a.

Schilling, J., Opiyo, F., and Scheffran, J.: Raiding pastoral livelihoods: Motives and effects of violent conflict in north-western Kenya, Pastoralism, 2, 1-16, 2012b.

Schilling, J., Vivekananda, J., Nisha, P., and Khan, M. A.: Vulnerability to environmental risks and effects on community resilience in mid-west nepal and south-east Pakistan, Environ. Nat. Resour. Res., 3, 1-19, 2013. 
Schilling, J., Akuno, M., Scheffran, J., and Weinzierl, T.: On raids and relations: Climate change, pastoral conflict and adaptation in northwestern Kenya, in: Climate change and conflict: Where to for conflict sensitive climate adaptation in Africa?, edited by: Bronkhorst, S. and Bob, U., Berliner Wissenschaftsverlag, Berlin, 241-268, 2014.

Standard: Kenya could export crude oil next year, http: //www.standardmedia.co.ke/business/article/2000152394/

kenya-could-export-crude-oil-next-year, last access: 1 April 2015.

Star: Turkana wants $25 \%$ share of oil wealth, http://www.the-star. co.ke/news/article-14618/turkana-wants-25-share-oil-wealth, last access: 2 November 2012.

Switzer, J.: Oil and violence in sudan: http://www.iisd.org/pdf/ 2002/envsecoil_violence.pdf (last access: 14 April 2014), 2002.

Tiab, D. and Donaldson, E. C.: Petrophysics, Gulf Professional Publishing, Boston, 2012.

Transparency International: Corruption perceptions index 2014, https://www.transparency.org/cpi2014/results (last access: 10 March 2015), 2014.

Tullow: Tullow builds on scholarship success: http: //www.tullowoil.com/index.asp?pageid=137\&category= \&year $=$ Latest $\&$ month $=\&$ tags $=84 \&$ newsid $=855$ (last access: 14 April 2014), 2013a.

Tullow: Kenya operations update, http://www.tullowoil.com/index. asp?pageid $=137 \&$ category $=\&$ year $=$ Latest $\&$ month $=\&$ tags $=$ 84\&newsid=862 (last access: 14 April 2014), 2013b.

Tullow: Tullow in Kenya, http://www.tullowoil.com/Media/docs/ default-source/operations/tullow-kenya-profile.pdf?sfvrsn=0 (last access: 1 April 2015), 2014a.
Tullow: Kenya, http://www.tullowoil.com/index.asp?pageid=432 (last access: 14 April 2014), 2014b.

Tullow: Operational update - Kenya, http://www.tullowoil. com/index.asp?pageid $=137 \&$ category $=\&$ year $=$ Latest $\&$ month $=$ $\&$ tags $=84 \&$ newsid=878 (last access: 14 April 2014), 2014c.

TUPADO: Turkana pastoralist organisation incident register 2000 2010, Lodwar, 2011.

UNDP: Kenya national human development report 2006, UNDP, Nairobi, 2006

UNDP: Kenya national human development report 2009, UNDP, Nairobi, 2010.

Vasquez, P. I.: Kenya at a crossroads: Hopes and fears concerning the development of oil and gas reserves, Int. Develop. Policy Anal., 4, 1-23, doi:10.4000/poldev.1646, 2013.

Vokes, R.: The politics of oil in Uganda, African Affairs, 111, 303314, doi:10.1093/afraf/ads017, 2012.

Wenar, L.: Fighting the resource curse, Global Policy, 4, 298-304, doi:10.1111/1758-5899.12069, 2013.

Wepundi, M., Nthiga, E., Kabuu, E., Murray, R., and Alvazzi del Frate, A.: Availability of small arms and perceptions of security in Kenya: An assessment, Graduate Institute of International and Development Studies, Geneva, 2012.

World Bank: World development report 2014, risk and opportunity: Managing risk for development, World Bank, Washington, 2014.

World Bank: Kenya's devolution, http://www.worldbank.org/en/ country/kenya/brief/kenyas-devolution, last access: 9 October 2015 . 